\title{
Transmission Channels of Public Investments Effects on Economic Growth: Case of the CEMAC Sub-region
}

\author{
Ibrahim Nji Ngouhouo \\ Associate Professor, Vice Dean, \\ Academic Affairs and Programming, \\ Faculty of Economics and Management, \\ University of Dschang \\ Corresponding Author

\section{Samuel Honoré Ntavoua} \\ Assistant Lecturer, \\ Faculty of Economics and Management, \\ University of Yaoundé II-SOA
}

Doi: $10.2478 / m j s s-2018-0113$

\begin{abstract}
The main objective of this research is to locate channels through which public investment can be forwarded in order to impact economic growth in the CEMAC sub-region. To achieve this goal, a dynamic generalized method of moments (GMM) and the two-stage least squares (TSLS) methods have been applied. Data to test our two hypotheses were collected from various sources. The results have shown that there effectively exist significant direct and indirect effects of public investment on economic growth. We also discovered that export and employment are being considered as the last shackles of the chain. To that effect, it is recommended to the CEMAC authorities to grant more interest to these variables during the elaboration of public investment policies.
\end{abstract}

Keywords: Public Investment, Transmission Channels, Economic Growth.

\section{Introduction}

The countries of the Economic and Monetary Community of Central Africa (CEMAC) are concerned with making their economy prosperous and sustainable, even emerging by 2025 . Thus, the economic development axes are well defined in the Regional Economic Program (PER), where the promotion of dialogue between the public and private sectors cannot take place alongside this momentum. For this reason, the CEMAC pays particular attention to public investment attraction policies; With a view to creating an enabling environment for the private sector to flourish.

In the aftermath of the 1980s crisis, and through the Structural Adjustment Programs (SAPs) and the completion point reached, several factors have influenced the evolution of public investment, and even its impact on the economy of the CEMAC. Indeed, we first note the cooperation with the IMF under the Heavily Indebted Poor Countries Initiative (HIPC), the reorganization of the tax revenues and the interest rate. Secondly, the creation of the politicoinstitutional factors, such as the advent of democracy in the 1990s, anti-corruption institutions, etc. Finally, some structural factors such as demography and urbanization were put in place in order to push the sub-region to adopt a rational attitude towards public investment policies. In Central Africa sub-region, five out of six countries are oil producers; which means that the CEMAC has the oil and the fiscal resources favorable to the financing of public investments. 


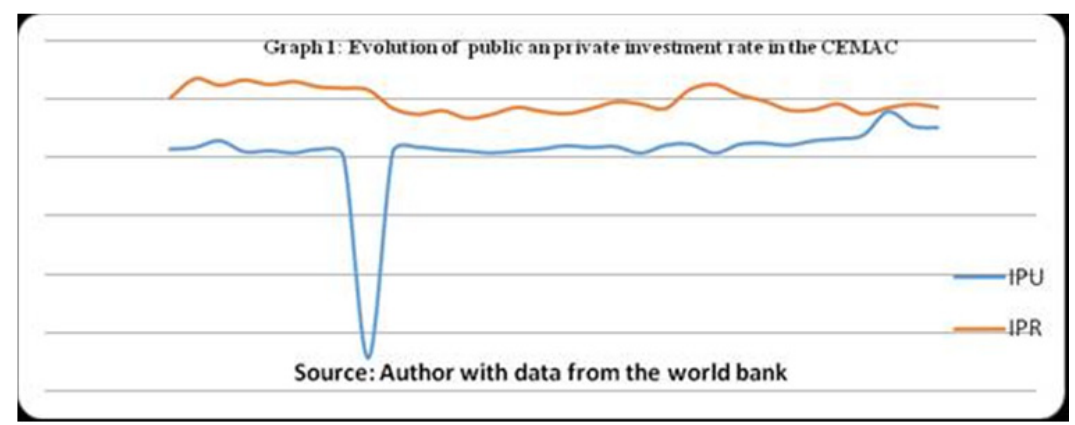

Thus, the effect of investments on the economic growth of the CEMAC has been recognized through its evolution in value. As compared to private investment, public investment is inferior in value in the sub-region. This tendency shows that, the contribution of public investment on economic growth is in most cases inferior to that of private investment according to Shoji (2001); Shah (1992); Rioja (2001) and Ramirez (1998). Indeed public investment in current dollars has passed from 925 millions in 2000 to 835 millions in 2010, contrary to that of 1990 to 2005 whose rate was positive and increased by 3.8 $\%$. This difference can be explained by the effective measures taken by the countries of the subregion that vary from one decade to another. It is clear that state intervention through public investment creates positive externalities throughout the economy. Indeed, public investment directed towards the development of socio-economic infrastructure and human capital is a guarantee of sustainable economic growth. Thus, our study aims to show how to help the CEMAC sub-region to boost growth through public investment. In other words, our main concern is to find the channels through which public investment can influence economic growth.

\section{Contributions of Public Investment in the CEMAC}

Figure 1 show that private investment is above public investment although the gap between these two variables is not very large and tends to be significantly confounded between 2008 and 2009 . Private investment declined between 1985 and 1999 and the increased between 2000 and 2005 can be explained by the economic crisis and the policy of economic liberalization. Public investment for its share declined from 1980 to 1985 and became negative between 1985 and 1990 .

Chart 2 shows that the share of public investment in Cameroon's total investments is higher from 1970 to 1995 and the smallest share belongs to Chad between 1995 and 2010. The rate of public investment varies from one country to another because the factors that are likely to influence it are heterogeneous. Also because public investment decisions are not commonly taken effectively by the member states, this attitude explains the failure of all these countries to comply with the convergence criterion. These investments are defined according to the priorities and, above all, on the basis of the poverty reduction strategies defined by each country. The effectiveness of private investment, despite the fact that it is mixed, has been reinforced as a result of the SAPs, with evidence of multiple privatizations and new directions for government action in public spending.

Chart 3 shows that well before 2002 the contribution of public investment was positive except in 1999 when it was negative. The positive evolution from 2004 to 2010 can be explained by the achievement of the completion point, which was considered by most of these countries as a breath of fresh air to the economy that enabled them to boost spending of public investment. Investments in most of these countries were infrastructural (roads, schools, hospitals).

In Cameroon, public investment in billions of FCFA is increasing, which corroborates with a positive contribution to economic growth. With maximum contribution in 2008 due to the development of multiple structuring projects (Lom Pangar damp, Kribi sea Port etc).

In Congo, the evolution in billions is also positive, rising from 181.8 to 458 in 2008, higher than that of Cameroon and considered second in absolute terms after Guinea in 2008. The contributions to growth is negative in 2003 and 2008 and are respectively 3.6 and 3.0; which is paradoxical and 
can be explained by a bad orientation that is not conducive to inclusive growth (BEAC, 2011).

In Gabon, the trend is positive with a maximum value in 2008 of CFAF 298.5 billion and a minimum value of 131 in 2003 . The low value of 2003 followed by 2004 explains in some ways the negative contribution of public investment. The rate of increase in public investment in billions is not consistent with its contribution to economic growth (1.6 and $0.4 \%$ respectively).

In Guinea, public investment in billions evolves positively and its contribution to economic growth was very high, around $15 \%$ in 2004 and 2006 . The values in billions in 2007 and 2008 were respectively 1018.8 and 1391.5 billion the highest value in Central Africa.

In Chad, the trend is also positive but declined in 2005 and reached a peak in 2008 . We note a negative contribution between 2005 and 2007, despite the positive and increasing trend of public investment in absolute terms.

Ultimately, the manipulation of public investments is tainted by many structural problems, mainly corruption and poor governance. This is why in most CEMAC countries the increase in investment in billions is not always a positive contribution to economic growth. It is up to member countries to develop an effective policy to promote public investment in line with a desired rate of economic growth.

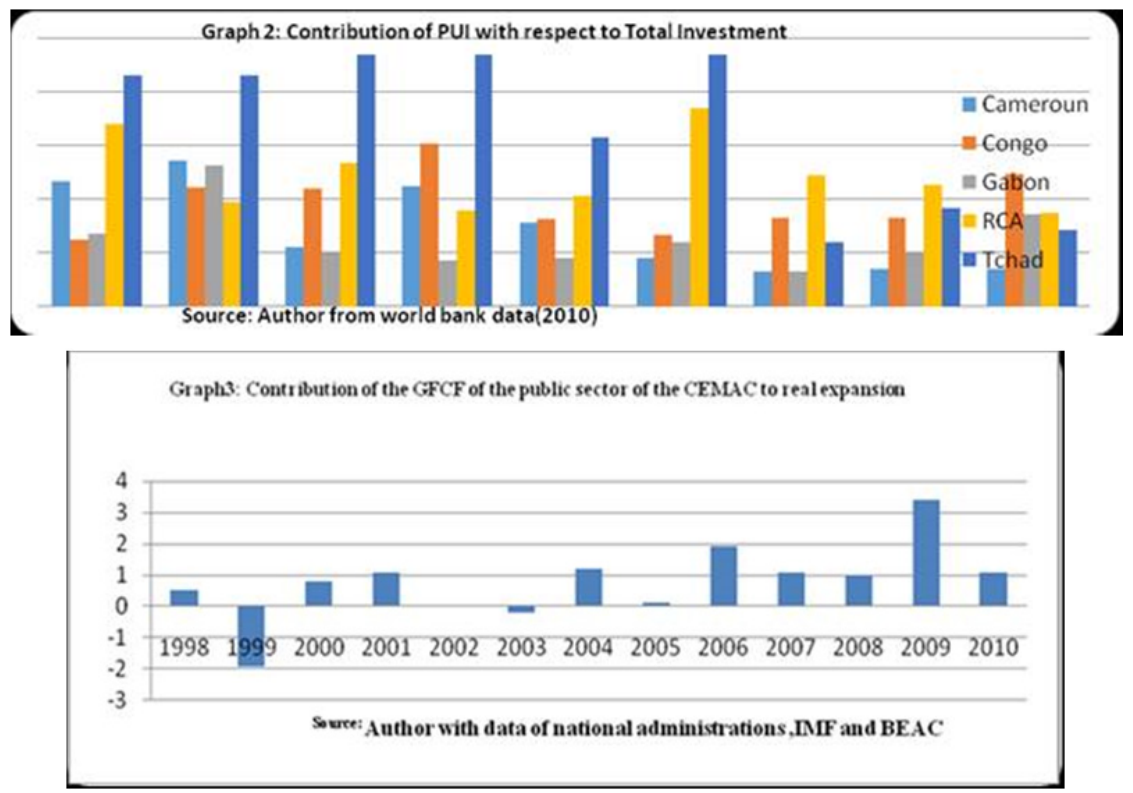

\section{Review of the literature}

\subsection{Theoretical review}

TheKeynesian growth model of Domar (1946) considers that investment has a double influence on the economy. On the demand side, the variation in investment determines the income level and the aggregate demand via the Keynesian multiplier principle $(\Delta \mathrm{I} \rightarrow \mathrm{Y} \rightarrow \mathrm{C}$ and $\mathrm{R})$. The income effect associated with an increase in investment $\Delta \mathrm{l}$ is equal to $\Delta \mathrm{l}[1 /(1-\mathrm{c})]$ ie $\Delta \mathrm{I}[1 / \mathrm{s}]$ where $\mathrm{s}$ is equal to1-c, knowing that $c$ and $s$ respectively represent the marginal propensities to be consumed and saved. On the supply side, investment increases production capacity. The capacity effect stipulates that investment must lead to a stimulation of the production capacity, via the accelerator mechanism. Investment increases production capacity by $1 / \mathrm{v}$ where $\mathrm{v}$ is the capital coefficient and is the inverse of the average productivity of capital, $v=K / Y$ (where $K$ is the stock of capital And $Y$ production (Muet, 1993). This approach places investment as one of the factors of economic growth. Specific cases of public and private investment have not been identified and this is why we 
are disaggregating investment to measure its contribution to economic growth through other factors such as savings, Debt, private investment, etc. From the neoclassical model, Solow (1956) attributes the origin of per capita growth to the amount of technical capital invested (machinery, equipment, software, infrastructure). When investment per capita exceeds the amount of existing per capita capital depreciation, each worker has more efficient equipment and can produce more. However, when investment per capita increased, production increases, but not proportionately (this is the principle of decreasing returns).

The neoclassical model goes beyond the simple physical assets framework to include human capital in all its forms: education, experience, health (Lucas, 1988). If the economy tends towards a stable equilibrium ratio between human capital and physical capital, this ratio may initially deviate from its long-term value. The magnitude of this gap will affect the rate at which the per capita product approaches its equilibrium level. The Solow model, which adds human capital investment to technical capital investment, serves to explain the convergence of some countries and the inequalities between poor and rich countries. Convergence stems from efforts to invest in human and technical capital in countries that are thus lagging behind.

Mankiw and al. (1992) propose to integrate into the Solow model the evolution of the quality of the workforce in order to better account for the progress of economic growth. This is justified by the fact that human capital can be increased by investing in the education system, the health system, and so on. Their analysis starts from the thesis that the accumulation of physical capital is not sufficient (in the Solow model) to explain the disparity of economic performances. The theories of endogenous growth are therefore based on the idea that economic activity needs imperfect competition and public intervention. Thus, the production function of the economy is a CobbDouglas and is written: $Y=k a H b(A L) 1-a-b$ with $a>0, b>0, a+b<1 . H$ represents the stock of human capital, $L$ is the number of workers and $K$ is the stock of capital. Its intensive form is $y=$ kahb with $y$ $=\mathrm{Y} / \mathrm{AL}, \mathrm{k}=\mathrm{K} / \mathrm{AL}$ and $\mathrm{h}=\mathrm{H} / \mathrm{AL}$. Its linear form gives Log $\mathrm{y}=$ aLogk + bLogh Knowing that the State intervenes on the basis of public investments in the socio-economic field (water, electricity, education, health, infrastructure, etc.), the following growth model should be tested; with Kpu the public capital which is approximated by the public sector gross fixed capital formation (GFCF) and $\mathrm{Kpr}$ the private capital approximated by the GFCF (Kpu, Kpr) of the private sector. Ultimately, this analysis enabled us to identify the factors likely to affect growth. More important is the highlighting of the intervention of the State, for which through certain initiatives, can influence economic growth. For example, the labor force, the construction of roads, could create a positive effect of training on the economy. Thus, this theoretical literature although determinant, does not specifically identify the factors through which public investment influences growth.

\subsection{Empirical review}

There exist an empirical debate around the relationship between investment and economic growth on one hand, and between public investment and private investment on the other hand. Results vary from one country to the other and according to the tests being used. It then results to either a complementary or substitution effect between public and private investments, or to significant effects (positive or negative) of investments or state action creating externalities favorable to economic growth.

Aschauer (1989) considers the relationship between aggregate productivity and stock and flow government-spending variables. The empirical results indicate that (i) the nonmilitary public capital stock is dramatically more important in determining productivity than is either the flow of nonmilitary or military spending, (ii) military capital bears little relation to productivity, and (iii) a 'core' infrastructure of streets, highways, airports, mass transit, sewers, water systems, etc. has most explanatory power for productivity. The paper also suggests an important role for the net public capital stock in the 'productivity slowdown' of the last fifteen years.

Munnell(1990a) reevaluates the original estimations of Aschauer (1989), and the works of holzeakin (1988); he finds that the overall impact of public capital on production and the productivity of the private sector are important. An increase of $1 \%$ in the stock of public capital will generate an increase of $0.34 \%$ in production. Given the amount of the stock of public capital and the level of production, this corresponds to a marginal productivity of about $60 \%$ for the public capital. For the second time, 
he examined the bond between public and economic activity at the level of states. Public capital had a real positive effect on production; public capital ameliorates the productivity of private capital, increasing its profitability and stimulating investments; the average employment evolution each year was determined according to variables that reflect production cost, the size of the market, and the level of taxation and the stock of public capital. Therefore, these 3 results show that public capital has a positive impact on the main aggregates like: production, investment and employment development.

The results of Munnell(1990b), had known some critics on the fact that the observations of the common tendencies between production and public infrastructures irritated a wrong correlation; the various studies carried rendered the coefficients suspicious and the causality effect doesn't move from public capital towards production, but it's the contrary.

Khan et al. (1990) examine the relative importance of public and private investment in promoting economic growth in a large group of countries in development. The study's results show that private and public investments have a different influence over economic growth, private investments have a much wider impact and direct than public investment. There were also changes in terms of effectiveness that public and private investments generate.

Devarajan et al.(1996) presented data on 43 countries in development, which proved that government spending does not have any significant effect on economic growth. Pritchett (1996) suggests another explanation for Devarajan, he discovers hypothesis "White Elephant", under which he argues that public investment in developing countries that are often used for projects are unproductive and inappropriate. As a result, the share of public investment may be too weak a measure to affect current public capital increase. Public investment should be a source of endogenous growth. A endogenous economic growth, which has output is stochastic trend, temporary policy changes have long-term consequences of output.

Barro (1991) examines the effect that bring public investment consumer and public spending in the economic growth of countries. After analysis of several variables, he confirmed that public investment didn't have any significant effect on economic growth rates, while the rate of economic growth negatively correlated with the share of consumer spending in government.

Nazmi and Ramirez (1997) analyzed the impact of public and private investment in Mexico. They jumped at the conclusion that public investment had a positive and significant effect in increasing the whole production. At the same time they concluded that the impact of public investment was statistically ident with the impact of private capital expenditures. The issue of whether additional public investment is an effective political strategy will depend primarily in the nature of the process of economic growth, as well as levels of public investment and other types of public spending.

Pradhan and al. (1990), carried out research in India on the question concerning the complementarily between public and private investment. From their results, it is noted that public investment and private investment varies the opposite way. When wages are well protected against increase in prices of goods, an increase in public investment ameliorates the distribution of revenue, favorable for economic growth.

Ford and Poret (1991), came out with similar statistically significant results. They extended the estimation of the model of Aschauer to 12 countries of the OCDE. The results are in line with the estimations of Aschauer for the USA, Canada, Belgium and Sweden. On the other hand, the stock of public capital is never significant for the United Kingdom, Norway and Austria.

Ngouhouo (2008) carried out a survey on the attractiveness and the economic effects of direct investment in five CEMAC countries. He came out with results according to which employment and export are channels through which investment touches economic growth in the region with a direct effect of public investment on economic growth.

With regards to what has been said, it is recognized that a complementary and a substitution effect between public and private investment on one hand; and a positive and significant effect of public investment on economic growth. The study of the channels of transmission of direct external investment has been carried out by Ngouhouo in the case of the CEMAC. The specific case of public investment is not very important, though authors such as Aschauer, Munnell, Reinhardt and khan dealt with factors that could link public investment influence to economic growth. It is the reason why we wish to begin from a dynamic model, study the channels of transmission of public investment effects on the economic growth of the CEMAC sub-region. 


\section{Methodology}

\subsection{Specification of the econometric model}

The model defined below is inspired from those of khan and Reinhardt (1990), Nazmi and Ramirez (1997), and of Ngouhouo (2008), the aim being to link public investments to other factors that can influence economic growth.

Equation 1 of employment (EMP)

$\mathrm{EMP}_{\mathrm{t}}=\mathrm{F}\left(\mathrm{IPU}_{\mathrm{t}}, \mathrm{EDU}_{\mathrm{t}}, \mathrm{IPR}_{\mathrm{t}}, \mathrm{IFR}_{\mathrm{t}}, \mathrm{EMP}_{\mathrm{t}-1}, \mathrm{IPU}_{\mathrm{t}-1}, \mathrm{IFR}_{\mathrm{t}-1}\right)$

Equation 2 of education (EDU)

$\mathrm{EDU}_{\mathrm{t}}=\mathrm{F}\left(\mathrm{IPU}_{\mathrm{t}}, \mathrm{IPR}_{\mathrm{t}}, \mathrm{IFR}_{\mathrm{t}}, \mathrm{EDU}_{\mathrm{t}-1, \mathrm{IPU}} \mathrm{t-1},\right)$

Equation3 of health (SAN)

$\mathrm{SAN}_{\mathrm{t}}=\mathrm{F}\left(\mathrm{IPU}_{\mathrm{t}}, \mathrm{SAN}_{\mathrm{t}-1}, \mathrm{IPR}_{\mathrm{t}}, \mathrm{IFR}_{\mathrm{t}}, \mathrm{IPU}_{\mathrm{t}-\mathrm{i}}, \mathrm{SAN}_{\mathrm{t}-\mathrm{j}}\right)$

Equation 4 of private investment (IPR)

$I_{P R}=F\left(I P U_{t}, E U_{t}, I F R_{t}, I P U_{t-1}\right)$

Equation 5 of exportation(EXP)

$\mathrm{EXP}_{\mathrm{t}}=\mathrm{F}\left(\mathrm{IPU}_{\mathrm{t}}, \mathrm{IPR}_{\mathrm{t}}, \mathrm{IFR}_{\mathrm{t}}, \mathrm{TCH}_{\mathrm{t}}, \mathrm{INF}_{\mathrm{t}}, \mathrm{TIN}_{\mathrm{t}}, \mathrm{CRO}_{\mathrm{t}}, \mathrm{IMP}_{\mathrm{t}}, \mathrm{EXP}_{\mathrm{t}-1, \mathrm{IPU}} \mathrm{It-1}\right)$

Equation 6 of importation(IMP)

$\mathrm{IMP}_{\mathrm{t}}=\mathrm{F}\left(\mathrm{IPU}_{\mathrm{t}}, \mathrm{IMP}_{\mathrm{t}-1}, \mathrm{IPR}_{\mathrm{t}}, \mathrm{IFR}_{\mathrm{t}}, \mathrm{TCH}_{\mathrm{t}}, \mathrm{INF}_{\mathrm{t}}, \mathrm{IPU}_{\mathrm{t}-1}, \mathrm{IMP}_{\mathrm{t}-\mathrm{i}}\right)$

Equation 7 of infrastructure(IFR)

$\mathrm{IFR}_{\mathrm{t}}=\mathrm{F}\left(\mathrm{IPU}_{\mathrm{t}}, \mathrm{IPR}_{\mathrm{t}}, \mathrm{CRO}_{\mathrm{t}}, \mathrm{INF}_{\mathrm{t}}, \mathrm{TCH}_{\mathrm{t}}, \mathrm{IFR}_{\mathrm{t}-\mathrm{i}}\right.$

Equation 8 estimation of growth without IPU (CRO)

$\mathrm{CRO}_{\mathrm{t}}=\mathrm{F}\left(\mathrm{EMP}_{\mathrm{t}}, \mathrm{EDU}_{\mathrm{t}}, \mathrm{SAN}_{\mathrm{t}}, \mathrm{IPR}_{\mathrm{t}}, \mathrm{EXP}_{\mathrm{t}}, \mathrm{IMP}_{\mathrm{t}}, \mathrm{IFR}_{\mathrm{t}}, \mathrm{CRO}_{\mathrm{t}-\mathrm{i}}\right)$

Equation 9 estimation of expansion with IPU

$\mathrm{CRO}_{\mathrm{t}}=\mathrm{F}\left(\mathrm{IPU}_{\mathrm{t}}, \mathrm{X}(\mathrm{k})_{\mathrm{t}}, \mathrm{CRO}_{\mathrm{t}-1}\right)$

The first seven equations takes the form $Y=F\left(P U I_{t}, X(k)_{t}\right)$ with $Y$ : the dependent variable, $X=$ other independent variables, Equation 9 takes the form $E X P_{t}=F\left(I P U_{t}, x(k)_{t}, E X P_{t-1}\right)$ with $x(k)$ : $Y$ variables that significantly influences growth (equation 8 )

\subsection{Methods and estimation procedures}

Sources of data are from international institutions such as: World Bank CD-ROM. The E-VIEWS.6 software has been used to analyze the data.

The Two Stage Least square method and the Generalized Method of Moment were with instrumental variables were used for the estimation. The particularity of this method is that, the version used (White version) is free from autocorrelation and Heteroschedasticity.

\section{Results and Interpretation}

\subsection{Effect of Public Investment on employment and education}

Table1 below shows that public and private investments significantly influence employment. Everything being equal, an increase in public investment leads to a more than proportionate increase in employment. This is explained in the CEMAC case where she is preoccupied by the creation of employment and the promotion of self-employment.

Notwithstanding its impact on education, variables explain education at the level of $39 \%$ and only a lag one and two in education are significant. Public investment has a positive sign, which means that, though it is not significant, public investment and education varies the same way. The sub-region cannot stray indifferent to the education of the population. We just can think that the efforts undertaken in the health domain are necessary but not significant. 
Table 1: Estimation of employment and education

\begin{tabular}{|c|c|c|c|c|c|c|c|}
\hline \multicolumn{3}{|c|}{$\begin{array}{c}\text { Dependant variable: EMP } \\
\text { Generalized method of moments and } \\
\text { two-stage least squares } \\
\text { Period : 1980- 2010 }\end{array}$} & \multicolumn{3}{c|}{$\begin{array}{c}\text { Dependant variable: EDU } \\
\text { Generalized two-stage least squares } \\
\text { Period : 1980- 2010 }\end{array}$} \\
\hline Variables & Coefficients & t-statistic & Prob. & Variables & Coefficients & t-statistic & Prob \\
\hline C & 25592297 & 3.066700 & 0.0061 & C & 47.95825 & 0.722770 & 0.4791 \\
\hline EDU & -3574.063 & -1.101021 & 0.2840 & IPU & 0.216367 & 0.856029 & 0.4032 \\
\hline IPU & $\mathbf{4 8 0 0 2 . 2 7}$ & $\mathbf{1 . 9 2 3 1 6 2}$ & 0.0688 & IFR & -1.291001 & -0.752087 & 0.4617 \\
\hline IFR & 290433.5 & 0.292610 & 0.7728 & IPR & -1.248872 & -0.477005 & 0.6391 \\
\hline IPR & $-\mathbf{6 1 6 7 5 7 . 0}$ & $\mathbf{- 1 . 7 5 7 7 8 6}$ & 0.0941 & EDU (-1) & $\mathbf{0 . 7 7 4 3 9 2}$ & $\mathbf{4 . 7 6 1 6 8 9 ^ { * }}$ & $\mathbf{0 . 0 0 0 2}$ \\
\hline EMP (-1) & 0.006126 & 0.421465 & 0.6779 & EDU (-2) & $-\mathbf{- 0 . 6 1 5 6 7 1}$ & $\mathbf{- 2 . 3 2 6 5 7 ^ { * * }}$ & $\mathbf{0 . 0 3 1 9}$ \\
\hline IFR (-1) & -340747.7 & -0.297472 & 0.7692 & EDU (-3) & 0.380745 & 1.484004 & 0.1551 \\
\hline IPU (-1) & $\mathbf{8 9 0 0 5 . 9 8}$ & $\mathbf{2 . 9 5 1 5 4 2}$ & 0.0079 & EDU (-4) & -0.254921 & -1.271099 & 0.2199 \\
\hline$R^{2}=0.025$ & DW $=2.02$ & $R^{2}=0.39$ & DW $=1.933$ \\
\hline
\end{tabular}

Source: Author, significant at $1 \%\left({ }^{*}\right), 5 \%\left({ }^{* *}\right)$, and $10 \%\left({ }^{* * *}\right)$ level

\subsection{Effect of Public Investment on Health}

Table2 below shows that the variables explain health at the level of $71 \%$. Infrastructures, investment, both private and public significantly influence health. In fact, all thing being equal, an increase by one unit in public investment will lead to an increase in health of 0.014277 units. This situation is well observed in the region by the evidence of rural and urban facilities concerning the coverage of vaccination and the outburst of health centers.

This same table shows that, variables put into evidence explains infrastructure at the level of $96 \%$. Inflation and public investment are significant. In fact, everything being equal, an increase by one unit in public investment leads to an increase in infrastructure of 1.04 units. This situation is well explained in the sub-region where being emergent by 2025 has become the norm. Public investment budget destined to the amelioration of socio-economic infrastructure has drastically increased in member countries. In fact, the countries are on the building sites of the infrastructural development plan

Table 2: Estimation of health and infrastructure Equation

\begin{tabular}{|c|c|c|c|c|c|c|}
\hline \multicolumn{4}{|c|}{$\begin{array}{c}\text { Dependant variable : SAN } \\
\text { Generalized two-stage least squares } \\
\text { Period : } 1980-2010\end{array}$} & \multicolumn{3}{|c|}{$\begin{array}{c}\text { Dependant variable : IFR } \\
\text { Generalized two-stage least squares } \\
\text { Period : } 1980-2010\end{array}$} \\
\hline Variables & Coefficients & t-statistic & Prob & Variables & Coefficients & t-statistic \\
\hline C & 3.906046 & 0.971273 & 0.3450 & C & 0.414373 & 1.166668 \\
\hline EDU & -0.000410 & -0.377784 & 0.7103 & $\mathrm{TCH}$ & -0.000781 & -1.022349 \\
\hline IPU & 0.003667 & 0.822062 & 0.4224 & INF & -0.286385 & $1.929109^{\star \star \star \star ~}$ \\
\hline IFR & 0.838462 & $4.538516^{*}$ & 0.0003 & TIN & 0.003597 & 0.447215 \\
\hline IPR & 0.158984 & $2.109528^{* *}$ & 0.0500 & IPU & 1.043057 & $1.885862^{\star \star \star}$ \\
\hline SAN(-1) & 0.074239 & 1.190103 & 0.2504 & CRO & 0.024289 & 1.567989 \\
\hline SAN(-2) & -0.175190 & -1.023976 & 0.3202 & IFR(-1) & 1.687968 & $12.20476^{*}$ \\
\hline IPU(-1) & 0.010407 & 1.476591 & 0.1581 & IFR(-2) & -0.758578 & $-4.322396^{*}$ \\
\hline IPU(-2) & 0.014277 & $1.756133^{\prime \prime}$ & 0.0971 & \multirow{3}{*}{\multicolumn{2}{|c|}{$R^{2}=0.96$}} & \multirow{3}{*}{$\mathrm{DW}=1.89$} \\
\hline $\mathrm{IPU}(-3)$ & 0.013053 & 1.729528 & 0.1018 & & & \\
\hline$R^{2}=$ & & \multicolumn{2}{|c|}{$\mathrm{DW}=2.2$} & & & \\
\hline
\end{tabular}

Source: Author, significant at $1 \%\left({ }^{*}\right), 5 \%\left(^{* *}\right)$ and $10 \%\left({ }^{* * *}\right)$.

\subsection{Effect of Public Investment on Private Investment}

Table 3 shows that public investment significantly and positively influences private investment at the level of $10 \%$. An increase by one unit in public investment leads to an increase in private 
investment by 2.81 units. The orientation given to public investment by the CEMAC in the supply of energy in recent years is welcomed as concerns private investment.

This result testifies of the partnership that has been put in place between the private and the public sector contained in the regional economic program.

Table 3: Estimation of private investment Equation

\begin{tabular}{|c|c|c|c|}
\hline \multicolumn{4}{|c|}{$\begin{array}{c}\text { Dependant variable : IPR } \\
\text { Generalized two-stage least squares } \\
\text { Period: } \mathbf{1 9 8 5} \text {-2012 }\end{array}$} \\
\hline Variables & Coefficients & t-statistic & Probabilities \\
\hline C & 19.49984 & 8.214716 & 0.0000 \\
\hline EDU & 0.005989 & 0.968297 & 0.3434 \\
\hline IFR & -0.156804 & -0.615715 & 0.5444 \\
\hline IPU(-1) & 0.031624 & 1.265913 & 0.2188 \\
\hline IPU & $\mathbf{0 . 0 6 4 2 8 7}$ & $\mathbf{2 . 8 1 9 1 2 7}$ & $\mathbf{0 . 0 1 0 0 ^ { * * * }}$ \\
\hline \multicolumn{4}{|c|}{ DW $=0.66$} \\
\hline
\end{tabular}

Source: Author, significant at $1 \%\left({ }^{*}\right), 5 \%\left({ }^{* *}\right)$ and $10 \%\left({ }^{* * *}\right)$ level

\subsection{Effect of public investment on export and import}

Table 4 shows that variables put into evidence explain export at $87 \%$. Economic growth and public investment influences positively and significantly export. An increase in by one unit in public investment leads to an increase in exportation by 3.44 units. This is explained by an increase in the investment budget orientated in the agricultural and petroleum domain where each country possesses a relative comparative or absolute advantage.

The same table also shows that the variables explain importation at the level of $86 \%$. Inflation, private investment, education, and infrastructure significantly influence import. Public investment on part is not significant, this explains the strategies put in place by the CEMAC after the 1985 crisis (the state needs not any longer live beyond its resources). Pubic investment ought to facilitate private investment

Table 4: Estimation of export and import

\begin{tabular}{|c|c|c|c|c|c|c|c|}
\hline \multicolumn{4}{|c|}{$\begin{array}{c}\text { Dependant variable : EXP } \\
\text { Generalized method of moments } \\
\text { Period : } 1985-2012\end{array}$} & \multicolumn{4}{|c|}{$\begin{array}{c}\text { Dependant variable : IMP } \\
\text { Generalized two-stage least squares } \\
\text { Period : } 1985-2012\end{array}$} \\
\hline Variables & Coefficients & t-statistic & Prob & Variables & Coefficients & t-statistic & Prob \\
\hline$C$ & 8.153429 & 1.076357 & 0.2977 & $C$ & 4.628068 & 1.338974 & 0.1982 \\
\hline $\mathrm{TCH}$ & 0.006888 & 0.938795 & 0.3618 & INF & -0.400755 & -1.938781 & $0.0693^{* * *}$ \\
\hline INF & 0.167498 & 1.501244 & 0.1528 & IPR & 0.584103 & 1.748722 & $0.0984^{\star \star *}$ \\
\hline TIN & 0.142595 & 0.471740 & 0.6435 & $\mathrm{TCH}$ & 0.003389 & 0.356543 & 0.7258 \\
\hline IFR & 0.279801 & 0.698710 & 0.4948 & EDU & 0.017379 & 2.246585 & $0.0382^{* *}$ \\
\hline IPR & -0.373386 & -1.417672 & 0.1755 & IFR & 0.629956 & 1.949132 & $0.0680^{\star \star \star *}$ \\
\hline IPU & -0.028552 & -0.782312 & 0.4455 & $\mathrm{IPU}(-1)$ & 0.009858 & 0.556039 & 0.5854 \\
\hline CRO & 0.635140 & $3.732149^{\star *}$ & 0.0018 & IPU & 0.023886 & 0.965596 & 0.3478 \\
\hline $\operatorname{EXP}(-1)$ & 0.763514 & $6.302818^{*}$ & 0.0000 & IMP(-1) & 0.677334 & 3.667018 & $0.0019^{\star *}$ \\
\hline $\mathrm{IPU}(-1)$ & -0.027836 & -0.752781 & 0.4625 & $\operatorname{IMP}(-2)$ & 0.526728 & 2.070930 & 0.0539 \\
\hline $\mathrm{IPU}(-2)$ & -0.053621 & -1.484991 & 0.1570 & \multirow{3}{*}{\multicolumn{2}{|c|}{$R^{2}=0.86$}} & \multirow{3}{*}{\multicolumn{2}{|c|}{$D W=1.80$}} \\
\hline IPU(-3) & 0.034333 & $3.443392^{\star *}$ & 0.0033 & & & & \\
\hline \multicolumn{4}{|c|}{$R^{2}=0.87$} & & & & \\
\hline
\end{tabular}

Source: Author, significant at $1 \%\left(^{*}\right), 5 \%\left(^{* *}\right)$ and $10 \%\left(^{* *}\right)$ level

\subsection{Estimating economic growth with, and without public investment}

Table 5 below shows that public investment explains economic at 51\%. Employment, infrastructure, export and private investment also significantly influence economic growth. This corroborates with 
the exogenous and the endogenous expansion theory explaining the CEMAC case. An increase in private investment by one unit, everything being equal, increases economic growth by 0.2 units.

The estimation with IPU in the table shows that the variables explain at the level of $52.27 \%$ and there is an absence of auto correlation. Exportation, employment, health and public investment significantly influences expansion. In fact, an increase in public investment leads to an increase in economic growth at a lesser dimension. This can be explained in the CEMAC case where the preoccupation is that of accompanying the private sector by the state in the production through favoring business climate and ameliorating socio economic infrastructures.

Table 5: Estimation of growth

\begin{tabular}{|c|c|c|c|c|c|c|c|}
\hline \multicolumn{3}{|c|}{$\begin{array}{c}\text { Dependant variable : CRO ( without IPU) } \\
\text { Generalized method of moments } \\
\text { Period : 1983- 2012 }\end{array}$} & \multicolumn{3}{c|}{$\begin{array}{c}\text { Dependant variable : CRO (with IPU) } \\
\text { Generalized method of moments } \\
\text { Period : 1983 - 2012 }\end{array}$} \\
\hline Variables & Coefficients & t-statistic & Prob. & Variables & Coefficients & t-statistic & Prob. \\
\hline C & 5.107619 & 0.339643 & 0.7379 & C & 5.806095 & 0.771667 & 0.4485 \\
\hline EMP & 8.52 E-08 & -2.007974 & $0.0591^{* * *}$ & EMP & 0.006625 & 2.011644 & $0.0445^{* *}$ \\
\hline IFR & 0.559942 & -1.892085 & $0.0738^{* * *}$ & SAN & -0.584362 & -1.742957 & $0.0953^{* * *}$ \\
\hline SAN & -0.759639 & -1.359585 & 0.1899 & EXP & 0.181151 & 1.834418 & $0.0802^{* * *}$ \\
\hline EXP & 0.410310 & 2.721057 & $0.0136^{* *}$ & IMP & 0.034359 & 0.302981 & 0.7648 \\
\hline IMP & 0.049388 & 0.168247 & 0.8682 & IPR & 0.063828 & 2.118379 & 0.0343 \\
\hline EDU & -0.007922 & -0.467488 & 0.6455 & CRO(-1) & 0.488892 & 2.825193 & $0.0099^{*}$ \\
\hline IPR & 0.286385 & 1.929109 & $0.0673^{* * *}$ & IPU & -0.011837 & -0.517000 & 0.6103 \\
\hline CRO(-1) & -0.031558 & -0.124775 & 0.9020 & IPU(-1) & 0.097235 & 4.885716 & $0.0001^{*}$ \\
\hline \multicolumn{3}{|c|}{$\mathrm{D}-\mathrm{W}=2.16$} & \multicolumn{3}{|c|}{$\mathrm{R}^{2}=52.27$} \\
\hline
\end{tabular}

Source: Author, significant at $1 \%\left({ }^{*}\right), 5 \%\left({ }^{* *}\right)$, and $10 \%\left({ }^{* * *}\right)$ level.

\subsection{Analysis of transmission channels}

With regards to previous results, figure 1 below shows the different transmission channels through which public investment transits in order to touch economic growth. Public investment has a positive and a direct influence on economic growth. It transits through employment and export. Finally, it can on one hand transit respectively through private investment and employment, and on the other hand, through infrastructure, and export to influence economic growth.

Regardless of the path followed by public investment, employment and exportation are considered as the last shackles of the chain. This is to say, countries of the sub -region must

insist on the strategies of job creation and the diversification of export, and these strategies have to be consolidated. These results corroborate with those of Ngouhouo (2008); in the sense that employment and exportation no matter their starting point (public investment, direct external investment) directly impacts economic growth in the region.

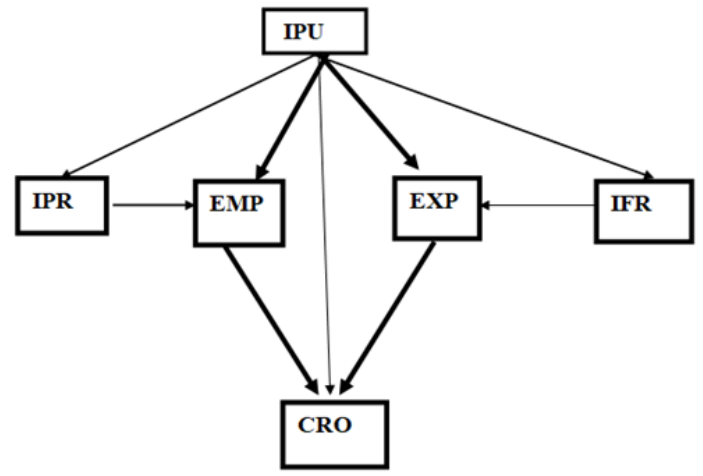

Figure 1: Synthetic result of transmission channels 


\section{Conclusion}

The aim of this research was to explain channels through wish public investment affect economic growth in the CEMAC countries. The methodology used in order to test the hypotheses was a dynamic model constituted of the GMM method and the TSLS with nine equations and some instrumental variables.

The results obtained show that, regardless of the nature of the path taken by public investment to reach economic growth, employment and export are considered as the last shackles of the chain. In order words, member countries must not divert from job creation and diversification of export strategies. This is why we advice not only member countries to rethink the multiple sources of financing of public investment but also to render this investment suitable in order to fight against poverty through the wealth and the job creation. The study of the causality will be of capital importance for it will permit us to see if expansion can be considered as starting point for the public investment financing.

\section{References}

Aschauer, D.A. (1989). Is public expenditure productive? Journal of Monetary Economics, XXIII (2), 177-200.

Barro, R. (1991). Economic growth in a cross section of countries. The Quarterly Journal of Economics, 106(2), 407-443.

BEAC. (2011). Conjoncture Economique et Financière des Etats Membres de la CEMAC en 2010 et Perspectives pour l'année 2011.

Devarajan, S., Swaroop,V. and Zou, H. F. (1996). The Composition of public expenditure and economic growth. Journal of Monetary Economics, (37), 313-344.

Domar, E. (1946). Capital Expansion, rate of Growth, and Employment», Econometrica 14 (2), 137-147.

Ford, R.,\&Poret, P.(1991). Infrastructure and private sector productivity. World development 19(2), 34-50.

Holz-Eakin, D. (1988). Private output, government capital, and the infrastructure crisis. Discussion Paper Series No 394, New York: Columbia University.

Khan, M. S., \& Reinhart, C. (1990). Private investment and economic growth in developing countries. World development, 18(3), $19-27$.

Lucas, R. E. Jr.(1988). On the Mechanics of Development Planning. Journal of Monetary Economics, XXII (1), 3-42.

Mankiw, N. G., Romer, D., \& Weil. (1992). A contribution to the empirics of economic growth. The quarterly journal of economics, 107(2), 407-437.

Muet, P. A. (1993). Les théories contemporaines de la croissance. Revue de l'OFCE, 11-51

Munnell, A.H. (1990a). Why has Productivity Growth Declined? Productivity and Public Investment. New England Economic Review, 1-20.

Munnell, A.H. (1990b). How Does Public Infrastructure Affect Regional Economic Performance? New England Economic Review, 11-32.

Nazmi, N. \& Ramirez, M.D. (1997). Public and Privatelnvestment and Economic Growth in Mexico, Contemporary Economic Policy, 15(1), pp.65-75.

Ngouhouo, I. (2008). Les investissements directs étrangers en Afrique Centrale: Attractivités et effets économiques », PhD Thesis in Economics, Université du Sud Toulon-var, LEAD.

Pradhan, B., Ratha. D., \&Sarma, A. (1990). Complementarity between public and private investment in India. Journal of Development Economics, 33(1), 101-116.

Ramirez, M. D. (1998). Does public investment enhance productivity growth in Mexico? A Cointegration Analysis. Eastern Economic Journal, 24(3), 63-82.

Rioja, F. K. (2001). Growth, welfare, and public infrastructure: A general equilibrium analysis of Latin American Economies. Journal of Economic Development, 26(2), 119-130.

Shah, A. (1992). Dynamics of public infrastructure, industrial productivity and profitability, Review of Economics and Statistics, 74, 28-36.

Shoji, J. (2001). Public capital and economic growth: A convergence approach". Journal of Economic Growth, 6, 205-227.

Solow, R. (1956). A contribution to the theory of economic growth, Quarterly Journal of Economics, 70(3), 65-94.

World Bank. (2010). African development indicator, washington DC. 